\section{Ronald Christenson}

Ronald Christenson, founder of the political science department at Gustavus Adolphus College in St. Peter, Minnesota, died in September 1998, after a two-year illness. He was that rarest of persons, a true teacher-scholar-activist.

Christenson, born in 1937, graduated from Wisconsin State University, Eau Claire in 1959 and received his master of arts and doctor of philosophy degrees in political science from the University of Minnesota.

He began his 34-year teaching career at Luther College in Decorah, Iowa. In 1969, he was called to Gustavus Adolphus to form a political science department and guide its growth over the years.

Christenson was, above all, a teacher. He received every major teaching award given by his college, including the Carlson Award for Distinguished Teaching. His reputation with students was "intellectual, knowledgeable, enthusiastic, and fair." His oral exams were legendary. Each final exam, he gave every one of his student an hour to engage in a dialog, with the student sitting in a rocking chair. During exam week, Christenson sat in his office for days on end, from seven in the morning until long into the evening, listening and talking with students.

Christenson was a prolific writer. He authored several books, including Political Trials: Gordian Knots in the Law (1986, with a revised edition completed just before his death) and Political Trials in History (1991). He also wrote introductory chapters of books by Roscoe Pound and Wallter Lippman, scholarly papers that won prizes, book reviews for popular newspapers and academic journals, regular newsletters for the students in his department, and articles for faculty journals.

Christenson was a citizen of his college, who was chosen by his peers year after year to serve on the Faculty Senate and other organs of faculty governance. He was a citizen of the nation, who worked for fair housing in Chicago with the Southern Christian Leadership Conference and took on every political task, from distributing campaign literature to serving as an alternate delegate at a national party convention. He was a citizen of the world, who founded an Amnesty International Chapter, brought students to Great Britain to study law in London, served on the Lutheran College Task Force for Peace and Justice, and took the risk during the apartheid era of spiriting out of South Africa the banned book Eye of the Needle so that it could be published abroad with his introduction.

Christenson accomplished more than others without ever seeming to move too fast. He was the most gentle, most considerate of persons. A devoted husband, father, and grandfather, he spent quality and quantity time with his family. He took time for friends and acquaintances and strangers. He had his views, and he had the courage to express them even when he was in the minority. But, without exception, he treated every person he encounteredfriend or adversary, college president or newly arrived student-with respect and kindness.

His was a good life.

\section{Donald Ostrom Gustavus Aldolphus College}

\section{Werner J. Feld}

Dr. Werner J. Feld, founding chair of the department of political science and Distinguished Professor at the University of New Orleans, passed away in September 1998, at his home in Colorado Springs, Colorado. At the time, Werner was working on the fourth edition of our textbook, International Organizations, and had just published the latest of his many scholarly books dealing with aspects of European integration.

Werner came to academia relatively late in life, having had careers in U.S. Army Intelligence and in business before entering Tulane University in the 1960s, from which he received his doctorate. From the outset of his academic career, he and his late wife Elizabeth were active in the foreign affairs community of New Orleans and played leading roles in the development of the new Louisiana State University in New Orleans, which was subsequently renamed to reflect the city it served.

In his dealings with many persons from various walks of life over a . very long time, Werner displayed a respect for cultural and social diversity and for personal tolerance. Born in Germany to Jewish parents, Werner emigrated to the United States with his family in the 1930s, where he became acculturated to American mores and culture without losing his love of things European, especially music. It is no accident, then, that when he embarked on a prolific writing career, he focused on the reconstitution of a Europe devastated by two disastrous wars. $\mathrm{He}$ not only studied, but fervently believed in employing, British theorist David Mitrany's concept of functionalism and French visionary Jean Monnet's notion of integration to settle long-standing nationalistic disputes and to eradicate war.

For most of his career at the University of New Orleans, and later at the Graduate School of International Studies at the University of Denver and the University of Colorado, Colorado Springs, Werner never neglected his teaching responsibilities. He loved to teach and was a reliable mentor and career facilitator. An example of this was his leadership of a successful effort to obtain a doctoral program for New Orleans by arguing that students coming from minority backgrounds needed expanded opportunities for graduate study.

He enjoyed the collegiality that comes from participating in professional organizations and societies. He was active in the Foreign Relations Association of New Orleans, in 